\title{
Preharvest Ethephon Eliminates First Crop Figs
}

\author{
Carlos H. Crisosto ${ }^{1,3}$, Vanessa Bremer ${ }^{1}$, Maxwell Norton ${ }^{1}$, \\ Louise Ferguson $^{1}$, and Todd Einhorn ${ }^{2}$
}

\begin{abstract}
AdDitional INDEX wORDs. Abscission, thinning, orchard sanitation, dried fruit beetle, Carpophilus hemipterus, aspergillum, Aspergillus, breba

SUMMARY. Most fig (Ficus carica) cultivars have potentially two crops; fruit from the first crop are called brebas. This crop is commercially important in some Mediterranean area cultivars. The second or main crop, called figs, is the commercially important crop for most fig cultivars. Due to labor cost increases, harvest of the breba crop, with its low production and lower quality fruit, has become economically unviable in some cultivars. Unharvested brebas are potential sites for fungal pathogens and they attract insects. Spring ethephon applications of 250 to $500 \mathrm{ppm}$ applied before full leaf expansion, when the largest fruit are about 1.5 to $2 \mathrm{~cm}$ in diameter reduced the breba crop load $(\approx 92 \%)$ without adverse side effects. The use of early fall ethephon applications of $500 \mathrm{ppm}$ also resulted in breba crop load reductions $(\approx 30 \%)$, but with significantly lower efficacy than spring treatments. These fall and/or spring ethephon treatments did not affect the percentage of vegetative budbreak, breba weight, breba soluble solids concentration, fig crop load, fig weight, or ethephon residues. Thus, early spring ethephon application at $300 \mathrm{ppm}\left(0.22-0.36 \mathrm{~kg} \cdot \mathrm{ha}^{-1}\right)$, when breba fruit and leaves are just starting to develop and figs are not present, was a safe, effective and inexpensive way (about \$16 per hectare) to reduce the breba crop. Currently, ethephon is included in the federal IR-4 program, and residue studies are ongoing as a protocol for future registration.
\end{abstract}

$\mathrm{F}$ ig is a nutritious fruit rich in fiber, potassium, calcium, and iron, as well as being an important source of vitamins, amino acids, and antioxidants (Chessa, 1997; Solomon et al., 2006; Stover et al., 2007). There are over 407,000 ha of figs worldwide, with an annual production of nearly 1 million tons (Food and Agriculture Organization of the United Nations, 2007). The United States ranks sixth in world production, primarily in the state of California, which has $\approx 5000$ ha (Stover et al., 2007). Fig trees, depending on the cultivar, may have one or two crops per year (Ferguson et al., 1990). The first crop of the season is called the breba crop and the second crop is called the main, or fig, crop. The breba crop is produced from overwintering fruit buds on 1-year-old shoots initiated the previous season (Petrucci and Crane, 1950), and matures around June in the San Joaquin Valley of California (Obenauf et al., 1978). Some cultivars are important breba producers and are very popular in some

${ }^{1}$ University of California, Davis, Department of Plant Sciences, I Shields Avenue, Davis, CA 95616

${ }^{2}$ Oregon State University, Mid-Columbia Agricultural Research Station, 3005 Experiment Station Drive, Hood River, OR 97031

${ }^{3}$ Corresponding author. E-mail: Carlos@uckac.edu.
Mediterranean production areas. The main or fig crop is produced from fruit buds that differentiate on the current season's shoots (Petrucci and Crane, 1950) and, in the San Joaquin Valley, matures around August to September (Obenauf et al., 1978). In most of the cultivars, the commercial crop is the main fig crop, while the breba crop yields are low to nearly nonexistent (Dominguez, 1990), with less flavorful and lower quality fruit (Doster and Michailides, 2007). For instance, for 'Conadria' fig, breba production represents $10 \%$ to $15 \%$ of the total annual crop (J. Gil, personal communication).

The fig industry has been affected by increased labor costs (Hendricks et al., 1994), rendering harvest of the breba crop economically unviable (Stover et al., 2007). Currently, matured, abscised brebas are blown to the row middles for later collection, or persist on the tree. In both cases, these brebas decay and become potential sites for fungal pathogens and attract insects. In addition, spores produced on infected breba fruits can infect the commercial crop (Doster and Michailides, 2007) and sharply decrease the main crop production and value (Michailides, 2003). Without effective pest and disease control, these preharvest diseases will continue to develop after harvest. Furthermore, insects can damage fruit, increasing fruit decay susceptibility and becoming fungal vectors (Doster and Michailides, 2007). Consequently, cost-effective reduction or elimination of the breba crop would be beneficial for reducing decay and/or pest infestations.

Exogenous applications of ethylene-releasing compounds, plant growth regulators (PGRs) used to thin fruit, have been effective in improving fruit yield and quality and decreasing production costs in other fruit commodities. Ethephon is the a.i. $(21.7 \%)$ in Ethrel ${ }^{\circledR}$ (Bayer Crop Science, Research Triangle Park, NC), a systemic PGR that, in solutions of $\mathrm{pH} 4$ or higher, decomposes to ethylene, phosphate, and chloride ions (Royal Society of Chemistry, 2007). Ethylene is widely recognized as an effective agent for accelerating fruit ripening and senescence.

Fig fruit growth occurs in three stages, described by a double sigmoid curve [i.e., initial and final stages of rapid growth (periods 1 and 3 ) separated by a stage of relatively slow growth (period 2)] (Chessa, 1997; Crane and Brown, 1950; Ferguson et al., 1990). The final growth (period 3 ) of breba figs coincides with period I

\begin{tabular}{llll}
\hline $\begin{array}{l}\text { Units } \\
\text { To convert U.S. to SI, } \\
\text { multiply by }\end{array}$ & U.S. unit & SI unit & $\begin{array}{l}\text { To convert SI to U.S., } \\
\text { multiply by }\end{array}$ \\
\hline 0.4047 & acre $(\mathrm{s})$ & $\mathrm{ha}$ & 2.4711 \\
0.3048 & $\mathrm{ft}$ & $\mathrm{m}$ & 3.2808 \\
3.7854 & gal & $\mathrm{L}$ & 0.2642 \\
9.3540 & gal/acre & $\mathrm{L} \cdot \mathrm{ha}^{-1}$ & 0.1069 \\
2.54 & inch(es) & $\mathrm{cm}$ & 0.3937 \\
6.4516 & inch & $\mathrm{cm}^{2}$ & 0.1550 \\
0.4536 & $\mathrm{lb}$ & $\mathrm{kg}$ & 2.2046 \\
1.1209 & $\mathrm{lb} / \mathrm{acre}^{2}$ & $\mathrm{~kg} \cdot \mathrm{ha}^{-1}$ & 0.8922 \\
0.0703 & $\mathrm{lb} / \mathrm{inch}^{2}$ & $\mathrm{~kg} \cdot \mathrm{cm}^{-2}$ & 14.2233 \\
28.3495 & $\mathrm{oz}$ & $\mathrm{g}$ & 0.0353 \\
1 & $\mathrm{ppm}$ & $\mathrm{mg} \cdot \mathrm{L}^{-1}$ & 1
\end{tabular}


growth of the main commercial crop, increasing the sink demand, potentially resulting in reduced fruit size of the commercial crop. Application of ethephon to 'Black Mission' fig branches, without brebas present, has produced different effects depending on the stage of fig development (Crane et al., 1970a, 1970b). When applied at concentrations of $500 \mathrm{ppm}$ near commercial harvest, fig ripening was enhanced by the ethephon treatment. However, when applied at concentrations of $500 \mathrm{ppm}$ during stage I, ethephon inhibited fruit growth and triggered fruit abscission within 5 to 6 d (Crane et al., 1970a, 1970b). Only minimal, occasional, vegetative responses, such as leaf epinasty and leaf abscission, were observed (Crane et al., 1970a, 1970b). Fig fruit abscission was observed in our preliminary study on 'Brown Turkey' and 'Conadria', in which 500 ppm ethephon was applied to 12 branches per cultivar in period 1 of fig growth development (V. Bremer and C.H. Crisosto, unpublished data). However, these studies were done on isolated branches of figs and might be expected to produce different results when applied to whole canopies with brebas, main crop figs, and leaves present. Ethephon applications in fall during leaf drop have been shown to delay bloom in peach and prune, depress floral bud freezing point, and to reduce crop load. A fall application of 200 ppm ethephon (at 10\% leaf abscission) to 'Suncrest' peach delayed bloom $8.8 \mathrm{~d}$ and reduced total crop by 73\% (Crisosto et al., 1990). Fall applications of 500 ppm ethephon on peach produced severe injury to flower buds and prevented some flowers from opening (Anderson and Seeley, 1993), and reduced cell division of the flower buds, resulting in significantly smaller buds and pistils (Gianfagna, 1989). Fall ethephon applications, not yet tested on fig trees, might be another method of reducing the breba crop.

Therefore, we evaluated the effect of fall (leaf drop) and spring (stage $l$ of fig growth development) preharvest ethephon applications on breba crop load.

\section{Materials and methods}

Twelve-year-old trees of the cultivar Conadria were used for investigating the effect of ethephon on breba crop load in 2005-06 and 2006-07.
The trees were grown in a commercial fig orchard in Madera County, CA, with a plant spacing of $14 \times 24 \mathrm{ft}$. In 2007-08, three 'Conadria' commercial fig orchards were used: the orchard previously used in Madera $(\operatorname{orchard} A)$, a second orchard in Madera (orchard B), and an orchard in Chowchilla (orchard C). The plant spacing and tree age of orchards $\mathrm{B}$ and $\mathrm{C}$ was $10 \times$ $22 \mathrm{ft}$ with 18 -year-old trees, and $12 \times$ $28 \mathrm{ft}$ with 20 -year-old trees, respectively. To study the effect of preharvest ethephon applications on breba crop load, two growth stages were selected: fall (at leaf abscission) and/or spring (during period $\mathrm{l}$ of breba fruit growth) treatment.

Fall treatment. For the fall ethephon treatments, 96 trees were selected in 2006 and were subjected to two factors (chemical concentration and time of application) using a $4 \times 3$ factorial randomized complete block design (RCBD). Four treatments were tested: an untreated control (0), 0.05\% surfactant-only or $250 \mathrm{ppm}$ ethephon plus $0.05 \%$ surfactant, and $500 \mathrm{ppm}$ ethephon plus $0.05 \%$ Triton surfactant (Syngenta Crop Protection, Greensboro, NC). The treatments were applied during natural leaf abscission on 26 Oct., and on 3 and 14 Nov. Each treatment combination had eight replications. As in all the studies conducted herein, the experimental unit comprised a single tree separated from other treatments by a single guard tree on either side.

SPRING TREATMENT. For the spring ethephon treatments, 30 and 64 trees in 2006 and 2007, respectively, were selected and subjected to two factors (chemical concentration and time of application). The experimental design of the Spring 2006 and Spring 2007 ethephon treatments was a $3 \times 2$ and $4 \times 2$ factorial RCBD, respectively. Each treatment combination had five and eight replications in 2006 and 2007, respectively. In the Spring 2006 season, the treatments tested were an untreated control, $250 \mathrm{ppm}$ ethephon plus $0.05 \%$ surfactant, and $500 \mathrm{ppm}$ ethephon plus $0.05 \%$ surfactant. In 2007 , a $0.05 \%$ surfactant-only treatment was added. The sprays were applied at two different stages of leaf and breba development. The first application (30 Mar. 2006 and 16 Mar. 2007) was done at stage 1 , just before when leaves were fully expanded and the biggest fruit were about 1.5 to $2 \mathrm{~cm}$ in diameter when measured from the sides (Fig. 1). The second application (18 Apr. 2006 and 23 Mar. 2007) was applied halfway through stage 1 , when breba fruit and leaves were partially developed.

COMBINATION OF FALL AND SPRING TREATMENTS. In 2007-08, 24,24 , and 48 trees were randomly selected in orchards $\mathrm{A}, \mathrm{B}$, and $\mathrm{C}$, respectively, as described above. This season, the experimental design of the ethephon treatments was a $4 \times 3$ completely randomized design (four chemical concentrations and three locations). The trees were randomly subjected to four different treatments: 500 ppm ethephon applied on 2 Nov. 2007 (fall spray), $300 \mathrm{ppm}$ ethephon applied on 25 Mar. 2008 (spring spray), a combination of fall and spring sprays, and an untreated control. All ethephon treatments were applied with $0.05 \%$ surfactant. For orchards $A$ and $B$, each treatment was applied on six random trees. For orchard C, each treatment was applied on 12 random trees.

All ethephon treatments were applied to the entire tree, until runoff, using a modified SR 420 backpack blower/sprayer (Stihl, Virginia Beach, VA). For instance, in 2007-08 applications, 2.4, 2.3, and 3.7 $\mathrm{L}$ of solution per tree were used for orchards A, B, and $C$, respectively. Based on a treedensity of 320 trees per ha, these volumes are equivalent to 730,768 , and $1190 \mathrm{~L} \cdot \mathrm{ha}^{-1}, 0.22$ to $0.36 \mathrm{~kg} \cdot \mathrm{ha}^{-1}$ for the 300 -ppm spring application.

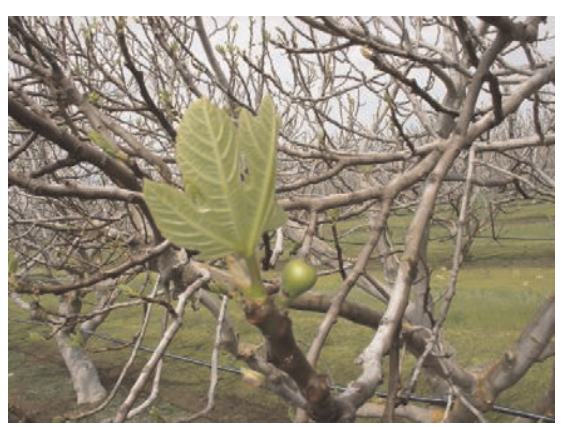

Fig. 1. First crop fig (breba) fruit and leaf development when the first ethephon application (30 Mar. 2006 and 16 Mar. 2007) was done at stage 1 , just before when leaves were fully expanded and the biggest fruit were about 1.5 to $2 \mathrm{~cm}(0.59-0.79$ inch) in diameter when measured from the sides. 
For each season, all fruit were harvested and counted at breba commercial maturity. Trunk circumference was measured at a distance of about $20 \mathrm{~cm}$ above the ground, converted to cross sectional area $\left(\mathrm{cm}^{2}\right)$ and used to express crop load (fruit $/ \mathrm{cm}^{2}$ ). Five to 15 randomly selected brebas per tree were used to calculate individual fruit weight and soluble solids concentration (SSC). For some trees, these measurements were not evaluated due to lack of fruit. The fruit were weighed together with a digital scale (model PM 4000; Mettler Instrument, Hightstown, NJ) and the weight was expressed as grams per fruit. Each fruit was then cut in half longitudinally, and one half of each fruit was used for SSC. The half fruits were wrapped together in two layers of cheesecloth and squeezed with a hand press to obtain a composite juice sample. The juice was used for determination of SSC with a temperature-compensated handheld refractometer (model ATC1; Atago, Tokyo) and the values were expressed as percentages. In addition, the fig crop was harvested at fig commercial maturity, weighed, and counted. These measurements were expressed as the number or weight of figs harvested per tree and/or per trunk cross-sectional area.

For vegetative measurements, the canopy was divided into four quadrants. Within each quadrant, one branch was randomly selected from midheight in the canopy on $28 \mathrm{Apr}$. 2006, 9 July 2007, and 28 May 2008. The percentage of vegetative budbreak was determined by dividing the number of new shoots on each branch by the total number of nodes. The length of the new apical shoot growth was also measured on these branches.

Commercially mature breba fruits from trees sprayed with $1000 \mathrm{ppm}$ ethephon and figs from trees sprayed with $500 \mathrm{ppm}$ ethephon both applied on the second fall application (3 Nov.), and commercially mature figs from trees sprayed with 500 ppm ethephon on the first spring application (16 Mar., breba fruit and leaves starting to develop) were analyzed in 2007 for ethephon residues. Anresco Laboratories in San Francisco, CA, analyzed the fig samples for ethephon residues by the gas liquid chromatographic method of ethephon and fenoprop in apples, with a detection limit of 0.10 ppm (Cochrane et al., 1976).
Data analysis. The data were subjected to analysis of variance [multifactor analysis of variance (ANOVA)] and regression analysis with SPSS (base 16.0 for Windows; SPSS, Chicago), and significance was tested at $P \leq 0.05$. Mean separation was determined by Tukey's honestly significant difference (HSD) at $P \leq 0.05$.

\section{Results and discussion}

Fall treatments. From the ethephon treatments applied during Fall $2006(0,250$, and $500 \mathrm{ppm})$, ethephon at either concentration did not significantly reduce the number of brebas harvested per tree $(P=0.133)$ or the number of brebas harvested per trunk cross-sectional area $(P=0.106)$. The time of application and the interaction between concentration and time of application not did not have a significant effect on number of brebas harvested per tree or number of brebas harvested per trunk cross-sectional area. Also, the $0.05 \%$ surfactant treatment did not significantly affect breba crop load (Table 1). There were no significant differences between applications of 250 and 500 ppm ethephon and untreated ability to reduce the breba crop load, but crop load did decrease $20 \%$ and $35 \%$, respectively, with increasing concentration, (Table 1). Fall ethephon concentration, timing of application, and the interaction among treatments did not have a significant effect on budbreak, breba weight
(33.9 g), breba SSC (19.3\%), or number of figs counted per branch $15 \mathrm{~d}$ before fig harvest (data not shown).

SPRing TREATMENTS. Spring applications of 250 and 500 ppm ethephon significantly reduced breba crop load relative to the untreated control in 2006 , and untreated control and surfactant in 2007 (Tables 2 and 3). In both seasons, there were no significant differences between ethephon concentrations. These ethephon concentrations represented a $67 \%$ and $87 \%$ reduction in the number of brebas harvested per tree and a $76 \%$ and $97 \%$ reduction in the number of brebas harvested per trunk cross-sectional area from the untreated control in 2006 and 2007, respectively. As in the fall ethephon treatments, the $0.05 \%$ surfactant had no effect on the number of brebas harvested per tree or the number of brebas harvested per trunk crosssectional area (only evaluated in 2007 , Table 3).

In both seasons, the time of application did not significantly affect breba crop load. However, in the high breba crop season (2006), the first spring application (onset of breba fruit and leaf development) more effectively reduced breba crop load $(\approx 40 \%$ of the control) than the second application, roughly $70 \%$ of the control (Table 2 ), suggesting that young breba abscission is more sensitive to ethylene than mature brebas. The breba crop load in 2007 was very low (20.2 brebas per

Table 1. Effect of two ethephon fall concentrations [ 250 and $500 \mathrm{ppm}\left(\mathrm{mg} \cdot \mathrm{L}^{-1}\right)$ ] plus $0.05 \%$ surfactant, a treatment with only $0.05 \%$ surfactant (surfactant only), and a control (untreated) on the percentage of budbreak, the number of brebas harvested per tree, and the number of brebas harvested per trunk cross-sectional area (TCSA) in 2007 of 'Conadria' fig applied on 26 Oct. (first application), 3 Nov. (second application), and 14 Nov. (third application) 2006.

\begin{tabular}{lccc}
\hline Ethephon treatment & $\begin{array}{c}\text { Bud break } \\
(\%)\end{array}$ & $\begin{array}{c}\text { Brebas per } \\
\text { tree }(\text { no. })\end{array}$ & $\begin{array}{c}\text { Brebas per TCSA } \\
\left(\text { no. } / \mathbf{c m}^{2}\right)^{\mathbf{z}}\end{array}$ \\
\hline Untreated & $23.8^{\mathrm{y}}$ & 16.5 & 0.061 \\
Surfactant only & 23.3 & 18.7 & 0.064 \\
$250 \mathrm{ppm}$ & 21.9 & 14.4 & 0.052 \\
$500 \mathrm{ppm}$ & 23.9 & 11.8 & 0.039 \\
Ethephon concentration $(P)$ & 0.887 & 0.133 & 0.106 \\
Time of application & & & 0.058 \\
$\quad$ First application & 23.3 & 17.5 & 0.066 \\
$\quad$ Second application & 22.8 & 18.0 & 0.067 \\
$\quad$ Third application & 23.7 & 19.1 & 0.876 \\
$\quad$ Time of application $(P)$ & 0.910 & 0.952 & 0.106 \\
Interaction $(P)$ & 0.808 & 0.186 & \\
\hline
\end{tabular}

${ }^{\mathrm{z}}$ Circumference of the trunk of each tree was measured at a distance of about $20 \mathrm{~cm}$ ( 7.9 inches $)$ above the ground and was converted to cross sectional area; 1 breba $/ \mathrm{cm}^{2}=6.4516$ breba/inch ${ }^{2}$.

${ }^{y}$ Means followed by the same letter are not significantly different within a column via Tukey's honestly significant difference test at $P \leq 0.05$. 
Table 2. Effect of two ethephon spring concentrations [250 and $500 \mathrm{ppm}$ $\left(\mathrm{mg} \cdot \mathrm{L}^{-1}\right)$ ] plus $0.05 \%$ surfactant and a control (untreated) on the percentage of budbreak, the number of brebas harvested per tree, and the number of brebas harvested per trunk cross-sectional area (TCSA) in 2006 of 'Conadria' fig applied on 30 Mar. (early application), when breba fruit and leaves started to develop, and on 18 Apr. (late application), when breba fruit and leaves were partially developed.

\begin{tabular}{lccc}
\hline Ethephon treatment & $\begin{array}{c}\text { Bud break } \\
(\%)\end{array}$ & $\begin{array}{c}\text { Brebas per } \\
\text { tree }(\text { no. })\end{array}$ & $\begin{array}{c}\text { Brebas per TCSA } \\
\left(\text { no. } / \mathbf{c m}^{2}\right)^{\mathbf{z}}\end{array}$ \\
\hline Untreated & $30.7^{\mathrm{y}}$ & $70.2 \mathrm{a}$ & $0.324 \mathrm{a}$ \\
$250 \mathrm{ppm}$ & 26.9 & $23.3 \mathrm{~b}$ & $0.098 \mathrm{~b}$ \\
$500 \mathrm{ppm}$ & 28.1 & $23.1 \mathrm{~b}$ & $0.076 \mathrm{~b}$ \\
Ethephon concentration $(P)$ & 0.500 & 0.004 & 0.002 \\
Time of application & & & 0.133 \\
$\quad$ Early application & 30.8 & 28.2 & 0.202 \\
$\quad$ Late application & 26.2 & 49.5 & 0.100 \\
$\quad$ Time of application $(P)$ & 0.093 & 0.085 & 0.608 \\
$\quad$ Interaction $(P)$ & 0.462 & 0.452 & \\
\hline
\end{tabular}

${ }^{2}$ The circumference of the trunk of each tree was measured at a distance of about $20 \mathrm{~cm}(7.9$ inches $)$ above the ground and was converted to cross sectional area; $1 \mathrm{breba} / \mathrm{cm}^{2}=6.4516 \mathrm{breba} / \mathrm{inch}^{2}$.

${ }^{y}$ Means followed by the same letter are not significantly different within a column via Tukey's honestly significant difference test at $P \leq 0.05$.

Table 3. Effect of two ethephon spring concentrations [ 250 and $500 \mathrm{ppm}$ $\left(\mathrm{mg} \cdot \mathrm{L}^{-1}\right)$ ] plus $0.05 \%$ surfactant, a treatment with only $0.05 \%$ surfactant (surfactant only), and a control (untreated) on the percentage of budbreak, the number of brebas harvested per tree, and the number of brebas harvested per trunk cross-sectional area (TCSA) in 2007 of 'Conadria' fig applied on 16 Mar. (early application), when breba fruit and leaves started to develop, and on 23 Mar. (late application), when breba fruit and leaves were partially developed.

\begin{tabular}{lccc}
\hline Ethephon treatment & $\begin{array}{c}\text { Bud break } \\
(\%)\end{array}$ & $\begin{array}{c}\text { Brebas per } \\
\text { tree }(\mathbf{n o} .)\end{array}$ & $\begin{array}{c}\text { Brebas per TCSA } \\
\left(\mathbf{n o .} / \mathbf{c m}^{2}\right)^{\mathbf{z}}\end{array}$ \\
\hline Untreated & $22.7^{\mathrm{y}}$ & $20.2 \mathrm{a}$ & $0.066 \mathrm{a}$ \\
Surfactant only & 26.3 & $15.8 \mathrm{a}$ & $0.052 \mathrm{a}$ \\
$250 \mathrm{ppm}$ & 26.4 & $2.6 \mathrm{~b}$ & $0.010 \mathrm{~b}$ \\
$500 \mathrm{ppm}$ & 23.3 & $0.6 \mathrm{~b}$ & $0.002 \mathrm{~b}$ \\
Ethephon concentration $(P)$ & 0.286 & $<0.0001$ & $<0.0001$ \\
Time of application & & & 0.029 \\
$\quad$ Early application & 23.4 & 8.5 & 0.036 \\
Late application & 25.9 & 11.1 & 0.447 \\
Time of application $(P)$ & 0.148 & 0.346 & 0.696 \\
Interaction $(P)$ & 0.551 & 0.788 & \\
\hline
\end{tabular}

${ }^{2}$ The circumference of the trunk of each tree was measured at a distance of about $20 \mathrm{~cm}(7.9$ inches $)$ above the ground and was converted to cross sectional area; 1 breba $/ \mathrm{cm}^{2}=6.4516 \mathrm{breba} / \mathrm{inch}^{2}$.

${ }^{y}$ Means followed by the same letter are not significantly different within a column via Tukey's honestly significant difference test at $P \leq 0.05$.

tree in untreated trees), in comparison with 2006 (70.2 brebas per tree in untreated trees).

Ethephon treatments did not have an effect on breba weight or SSC (data not shown). Breba weight and SSC were $35.8 \mathrm{~g}$ and $20.9 \%$, respectively. In 2007, at fig commercial harvest, comparing untreated trees versus trees treated with 500 ppm ethephon, there were no significant differences in the number of figs harvested per tree (3500 figs), number of figs harvested per trunk cross-sectional area (57 figs/ $\mathrm{cm}^{2}$ ), or fig weight (43 g). Ethephon residues were not detected on any of the fruit analyzed in 2007, which included commercially mature breba fruits and main crop figs from trees sprayed with 500 ppm ethephon on 3 Nov. 2006, and commercially mature figs from trees sprayed with 500 ppm ethephon on 16 Mar. 2007. IR-4 residue studies are ongoing as a protocol for future registration.

COMBINATION OF FALL AND SPRING TREATMENTS. Combined spring and fall ethephon treatments had a significant effect on the number of brebas harvested per tree and the number of brebas harvested per trunk cross-sectional area. Spring application of 300 ppm ethephon and the combination of fall 500 ppm ethephon plus spring 300 ppm ethephon were the most effective treatments in reducing the breba crop. These treatments reduced the number of brebas harvested per tree and the number of brebas harvested per trunk cross-sectional area by $\approx 86 \%$ (Table 4 ). Although fall application of 500 ppm ethephon alone significantly reduced the number of brebas harvested per trunk cross-sectional area relative to the control (Table 4), it resulted in significantly more breba fruit on the trees than the spring treatment or the combination of fall and spring treatments. These results suggest that the spring 300 ppm ethephon treatment is the more effective component of the combined fall 500 ppm ethephon plus spring 300 ppm ethephon application. Thus, spring ethephon was the more effective and inexpensive treatment (about $\$ 16$ per hectare) to reduce the breba crop.

The number of brebas harvested per untreated tree varied among orchards (Table 4). Trees in orchard C (Chowchilla) yielded a higher number of brebas per untreated tree (153.2) than the orchards in Madera (79.8 and 62.8) for orchards $A$ and $B$, respectively, which may be due to the significantly higher trunk circumference (tree vigor) of the trees in orchard C. There was a positive and significant relationship between trunk circumference and the number of brebas harvested per untreated tree (adjusted $\left.\mathrm{R}^{2}=0.62, P=0.000\right)$. This explains the lack of statistical difference in the number of brebas harvested per trunk cross-sectional area among orchards (Table 4). Neither ethephon treatment nor orchard had a significant effect on the number of figs per branch counted $14 \mathrm{~d}$ before breba harvest (data not shown). At the same time, in orchard A (only orchard evaluated), none of the ethephon treatments had a significant effect on the total fig weight harvested per tree $(67.7 \mathrm{~kg} /$ tree), the total fig weight harvested per trunk cross-sectional area (0.19 $\mathrm{kg} \cdot \mathrm{cm}^{-2}$ ), or the average fig weight $(24.3 \mathrm{~g})$ in orchard A (Table 5 ).

These results indicate that the reduction of the first crop (breba) by ethephon does not affect the second or main crop yield (fig). In fact, the breba crop of the untreated control, under this orchard's conditions, did not 
Table 4. Effect of $500 \mathrm{ppm}\left(\mathrm{mg} \cdot \mathrm{L}^{-1}\right)$ ethephon applied on 2 Nov. 2007 (fall spray), 300 ppm ethephon applied on 25 Mar. 2008 (spring spray), a combination of both previous sprays (fall + spring sprays), and a control (untreated) on the percentage of budbreak, the number of brebas harvested per tree, and the number of brebas harvested per trunk cross-sectional area (TCSA) in three different locations (orchard A, orchard B, and orchard C) in 2008 of 'Conadria' figs. All ethephon treatments were applied with $0.05 \%$ surfactant.

\begin{tabular}{lccc}
\hline Ethephon treatment & $\begin{array}{c}\text { Bud break } \\
(\%)\end{array}$ & $\begin{array}{c}\text { Brebas per } \\
\text { tree }(\text { no. })\end{array}$ & $\begin{array}{c}\text { Brebas per TCSA } \\
\left(\mathbf{n o .} / \mathbf{c m}^{2}\right)^{\mathbf{z}}\end{array}$ \\
\hline Untreated & $26.2^{\mathrm{y}}$ & $189.4 \mathrm{a}$ & $0.439 \mathrm{a}$ \\
Fall $(500 \mathrm{ppm})$ & 24.2 & $149.6 \mathrm{a}$ & $0.320 \mathrm{~b}$ \\
Fall $(500 \mathrm{ppm})+$ Spring $(300 \mathrm{ppm})$ & 24.7 & $30.8 \mathrm{~b}$ & $0.074 \mathrm{c}$ \\
Spring $(300 \mathrm{ppm})$ & 27.5 & $23.5 \mathrm{~b}$ & $0.053 \mathrm{c}$ \\
Ethephon $(P)$ & 0.639 & 0.000 & 0.000 \\
$\quad$ Orchard & $21.9 \mathrm{a}$ & $79.8 \mathrm{a}$ & 0.225 \\
Orchard A & $29.5 \mathrm{~b}$ & $62.8 \mathrm{a}$ & 0.195 \\
Orchard B & $25.8 \mathrm{ab}$ & $153.2 \mathrm{~b}$ & 0.281 \\
Orchard C & 0.011 & 0.001 & 0.347 \\
Orchard $(P)$ & 0.963 & 0.127 & 0.518 \\
Interaction $(P)$ & &
\end{tabular}

${ }^{\mathrm{z}}$ Circumference of the trunk of each tree was measured at a distance of about $20 \mathrm{~cm}(7.9$ inches $)$ above the ground and was converted to cross sectional area; 1 breba $/ \mathrm{cm}^{2}=6.4516$ breba/inch ${ }^{2}$.

${ }^{y}$ Means followed by the same letter are not significantly different within a column via Tukey's honestly significant difference test at $P \leq 0.05$.

Table 5. Effect of $500 \mathrm{ppm}\left(\mathrm{mg} \cdot \mathrm{L}^{-1}\right)$ ethephon applied on 2 Nov. 2007 (fall spray), 300 ppm ethephon applied on 25 Mar. 2008 (spring spray), a combination of both previous sprays (fall + spring sprays), and a control (untreated) on the fig weight in orchard $\mathrm{C}$ in 2008. All ethephon treatments were applied with $0.05 \%$ surfactant.

\begin{tabular}{lccc}
\hline Ethephon treatment & $\begin{array}{c}\text { Fig wt per tree } \\
(\mathbf{k g} / \text { tree })^{\mathbf{z}}\end{array}$ & $\begin{array}{c}\text { Fig wt per TCSA } \\
\left(\mathbf{k g} \cdot \mathbf{c m}^{-2}\right)^{\mathbf{y}}\end{array}$ & $\begin{array}{c}\text { Fig wt } \\
(\mathbf{g})^{\mathbf{x}}\end{array}$ \\
\hline Untreated & 72.0 & 0.20 & 23.6 \\
Fall $(500 \mathrm{ppm})$ & 74.1 & 0.19 & 25.0 \\
Fall $(500 \mathrm{ppm})+$ Spring $(300 \mathrm{ppm})$ & 70.2 & 0.19 & 26.6 \\
Spring $(300 \mathrm{ppm})$ & 73.9 & 0.18 & 22.5 \\
Ethephon treatment $(P)$ & 0.825 & 0.458 & 0.679 \\
\hline
\end{tabular}

${ }^{\mathrm{z}} \mathrm{l} \mathrm{kg}=2.2046 \mathrm{lb}$.

yThe circumference of the trunk of each tree was measured at a distance of about $20 \mathrm{~cm}(7.9$ inches) above the ground and was converted to cross sectional area; $1 \mathrm{~kg} \cdot \mathrm{cm}^{-2}=14.2233 \mathrm{lb} / \mathrm{inch}^{2}$.

${ }^{\mathrm{x}} \mathrm{l} \mathrm{g}=0.0353 \mathrm{oz}$.

adversely impact fruit quality of the second crop as a result of increased competition for assimilates. This was probably due to the low amount of breba fruit relative to total tree canopy size. The results obtained in this study agree with the results observed by Crane et al. (1970a, 1970b) and with our preliminary study; both were branch studies. However, in this study, lower ethephon concentrations (250 vs. $500 \mathrm{ppm}$ ) provided satisfactory breba crop reduction. However, for fall leaf drop applications, ethephon concentrations higher than those recommended in peach (Prunus persica) were needed to reduce breba crop load.

Ethephon treatments did not have a significant effect on percentage of budbreak in any of the three test years (Tables 1-4). The only difference being higher for orchard A $(11.1 \mathrm{~cm})$ in comparison with orchards B and C (5.9 and $6.7 \mathrm{~cm}$, respectively). Trunk circumferences of the trees used in each trial within each orchard were similar, indicating comparable vigor and canopy size among experimental units. However, trunk circumferences differed among orchards, averaging $60 \mathrm{~cm}$ in orchard A in 2006-07, $65 \mathrm{~cm}$ in orchards A and B in 2008, and $83 \mathrm{~cm}$ in orchard $\mathrm{C}$ in 2008 . Ethephon treatments $(250$ and 500 ppm) did not cause any phytotoxicity. In a separate nonrandomized trial (full rows), we observed leaf epinasty and some leaf abscission on trees treated with Spring 1000 ppm ethephon when the breba fruit and leaves were partially developed (second application, 18 Apr. 2006 and 23 Mar. 2007).

\section{Conclusions}

These results demonstrate that a safe, inexpensive, and effective way to reduce breba crop has been developed for the fig industry. A very early spring ethephon application of 300 $\mathrm{ppm}$, when breba fruit and leaves are (Fig. 1) just starting to develop and figs are not present, effectively reduced breba crop load by $\approx 92 \%$. A 500 ppm fall ethephon application during leaf abscission also resulted in significant breba crop load reductions $(\approx 30 \%)$. However, the fall ethephon treatment was significantly less effective in breba reduction than the spring ethephon treatments. These fall and/ or spring ethephon treatments did not affect the percentage of budbreak, breba weight, breba SSC, fig crop load, fig weight, or ethephon residues. Currently, ethephon is included in the federal IR-4 program and residue studies are ongoing as a protocol for future registration.

A had significantly higher number of nodes per branch (13.9 nodes) than the other two orchards (9.3 nodes), and orchard $\mathrm{C}$ had significantly lower number of shoots per branch (1.9 shoots) than the two orchards in Madera (2.4 shoots). Therefore, orchard $\mathrm{B}$ had the highest percentage of budbreak (29.5\%) and orchard A had the lowest $(21.9 \%)$. In the two previous years (2006-07), the percentages of budbreak of orchard A was around $24.8 \%$. Length of the apical shoot was unaffected by ethephon treatments in 2008 (not measured in previous years, data not shown), but this measurement was different among orchards,

\section{Literature cited}

Anderson, J.L. and S.D. Seeley. 1993. Bloom delay in deciduous fruit. Hort. Rev. (Amer. Soc. Hort. Sci.) 15:97-145.

Chessa, I. 1997. Fig, p. 245-268. In: S. Mitra (ed.). Postharvest physiology and storage of tropical and subtropical fruits. $\mathrm{CAB}$ International, Wallingford, UK.

Cochrane, W.P., R. Greenhalgh, and N.E. Looney. 1976. Gas-liquid chromatographic analysis of ethephon and fenoprop residues in apples and their decline before and after harvest. J. Assoc. Off. Anal. Chem. 59:617-621. 


\section{Research Reports}

Crane, J.C. and J.G. Brown. 1950. Growth of the fig fruit, Ficus carica var. Mission. Proc. Amer. Soc. Hort. Sci. 56: 93-97.

Crane, J.C., N. Marei, and M.M. Nelson. 1970a. Ethrel speeds growth and maturity of figs. Calif. Agr. 24:8-10.

Crane, J.C., N. Marei, and M.M. Nelson. 1970 b. Growth and maturation of fig fruits stimulated by 2-chloroethylphosphonic acid. J. Amer. Soc. Hort. Sci. 95:367-370.

Crisosto, C.H., A.N. Miller, P.B. Lombard, and S. Robbins. 1990. Effect of fall ethephon applications on bloom delay, flowering, and fruiting of peach and prune. HortScience 25:426-428.

Dominguez, A.F. 1990. La higuera. Frutal mediterraneo para climas calidos. Ediciones Mundi-Prensa, Madrid, Spain.

Doster, M.A. and T.J. Michailides. 2007. Fungal decay of first-crop and main-crop figs. Plant Dis. 91:1657-1662.
Ferguson, L., T.J. Michailides, and H.H. Shorey. 1990. The California fig industry. Hort. Rev. (Amer. Soc. Hort. Sci.) 12:409490.

Food and Agriculture Organization of the United Nations. 2007. FAOSTAT. 24 Sept. 2009. <http://faostat.fao.org/site/ $567 /$ DesktopDefault.aspx?PageID $=567$ \# ancor $>$.

Gianfagna, T.J. 1989. Chemical control with ethephon of bud dormancy, cold hardiness, and time of bloom in peach trees. Quarterly J. Plant Growth Regulat. Soc. Amer. 17:39-47.

Hendricks, L., G. Leavitt, H. Andris, L. Ferguson, K. Klonsky, and P. Livingston. 1994. Sample costs to establish a fig orchard and produce figs. 3 Oct. 2008. <http://coststudies.ucdavis.edu/archived. php>.

Michailides, T.J. 2003. Diseases of fig, p. 1-19. In: R.C. Ploetz (ed.). Diseases of tropical fruit crops. CAB International, Cambridge, MA.
Obenauf, G., M. Gerdts, G. Leavitt, and J. Crane. 1978. Commercial dried fig production in California. Univ. California, Div. Agr. Sci. Lflt. 21051.

Petrucci, V.E. and J.C. Crane. 1950. Fruit bud initiation and differentiation in the fig. Proc. Amer. Soc. Hort. Sci. 56:86-92.

Royal Society of Chemistry. 2007. Ethephon. 20 Oct. 2007. <http://www.rsc. org/pdf/general/17etheph.pdf>.

Solomon, A., S. Golubowicz, Z. Yablowicz, S. Grossman, M. Bergma, H.E. Gottlieb, A. Altman, Z. Kerem, and M.A. Flaishman. 2006. Antioxidant activities and anthocyanin content of fresh fruits of common fig (Ficus carica L.). J. Agr. Food Chem. 54: 7717-7723.

Stover, E., M. Aradhya, C.H. Crisosto, and L. Ferguson. 2007. Overview of the California fig industry and new interest in varieties for fresh fruit. Proc. California Plant Soil Conf. p. 169-175. 